\title{
Tarihsel Gerçeklik ve Dram ilişkisi: Gerçek ya da Yapıntı Karakter Olarak Jeanne d'Arc
}

Tuğçe Gözde PELISTER *

Özet

Tarih algısının 19. yüzyıl içindeki değişimi, tarihsel metinlerin yazınsal metinlerle olan etkileşiminin incelenmesinin önemine vurgu yapmıştır. Tarihsel dramın malzemesi, değişen tarihsel ve yazınsal metin algısıyla bağımsız bir hal almıştır. Tarihsel bir figür olarak Jeanne d'Arc, Frederich Schiller, Bertolt Brecht, Bernard Shaw gibi oyun yazarları için dramatik malzemeye dönüşmüştür. Yapıntı Jeanne d'Arc, tarihsel gerçeklik ve dramatik karakter açısından farklı oyunlarda farklı biçimlerde yorumlanmıştır.

Anahtar Sözcükler: Tarih, Tarihsel gerçeklik, Tarihsel dram, Jeanne d'Arc.

\section{Relation Between Historical Reality And Drama: Jeanne d'Arc as Real or Fictional Character}

\begin{abstract}
The change in perception of history in 19th century has emphasized the importance of analysing the interaction between the historical and literary texts. The material of historical drama has come to a state of independence due to change in perpection of historical and literary texts. Jeanne d'Arc, as a historical figure, has become a dramatic material for play writers such as Frederich Schiller, Bertolt Brecht, Bernard Shaw. In different plays, Jeanne d'Arc, as a fiction character, has been interpreted differently in terms of historical reality and dramatic character.
\end{abstract}

Keywords: History, Historical reality, Historical drama, Jeanne d'Arc. 


\section{Tarihsel Gerçekliğin Gerçekliği}

Tarihsel gerçekliḡin nesnelliği, 19. yüzyılda 'Yeni Tarihselcilik'le sorgulanmaya başlamıştır. ilk olarak 1980 yılında Stephan Greenblatt ve Louise Montrose tarafından tanıtılan bu terim, 'Yeni Eleştiri' ve 'Yapısalcılık' gibi biçimsel yaklaşımlara bir tepki olarak ortaya çıkmıştır. Bir tür eleştirel yaklaşım olan Yeni Tarihselcilik, metnin tarihsel bağlamdan koparılıp zaman ve mekandan bağımsız, evrensel bir çerçevede incelenemeyeceği fikrini dile getirerek metnin içinde üretildiği tarihi ve kültürel koşulların önemini vurgulamıştır (Çavuş, 2002: 122). Yeni Tarihselciler, geçmişte yaşanan olayların nesneliği konusuna şüpheyle bakmış ve tarihin gerçeği olduğu gibi yansıtamayacağını iddia etmişlerdir. Tarihsel gerçeklik her zaman onu bilen kişinin yorumuyla doğru orantılı deḡişime uğrayıp deg̃işmektedir. Serpil Oppermann (2006: 7), 'Postmodern Tarih Kuramı' adlı kitabında, tarih yazımında geçmiş gerçekliğin yansıtılmasını önemli bir ontolojik sorun olarak nitelendirmektedir: "Aslında varlık düzeyinde geçmiş olaylar oldukları gibi var olmaktadır; ancak bunlara ilişkin bilgilerin doğrulukları ve yanlışlıkları metin düzeyinde kesinlikten uzaktır”. Bizlerin, geçmişi ancak tarihsel metinlere bakarak öğrenebileceğimizi ifade eden Oppermann (2006: 7), bu yüzden nesnel bir tarih anlayışının olup olamayacaḡına verilecek cevabın da olumsuz olacağını belirtmektedir.

Tarihin temelinde yazınsal bir metin oluşu ve sonunda metni oluşturan kişinin öznel seçimleri ve üslubuyla şekillenmesi, tarihin nesnelliğinin sorgulanmasına yol açmıştır. Tarihsel metinler yoruma dayalı göreceliği ve epistemolojik kuşkuculuğu anlatı bazında ön plana alan düşünümsel yazılardır. Bu nedenle, tarihsel bilginin özü keşfedilemez ve bu öz, bilginin ontolojik çözümlemesi yoluyla ortaya çıkarılabilecek bir öge deḡildir (Oppermann, 2006: 9-10). Tarihin epistomolojik olarak belirsizliḡinin yanı sıra çizgisel bir düzende olması da gerçekçi değildir. Tarih yazarının geçmiş olayları başı ve sonu olan bir hikaye gibi anlatması, kuşkusuz bu kurgunun doğrusal bir düzende devam ettiḡinin kanıtı olmayacaktır. Tarihsel söylemin hızla değişip dönüşmesi, beşeri bilimlerin hızla değişmesiyle doğru orantılıdır. Oppermann (2006: 11), neden-sonuç ilişkilerine oturtularak yazılan tarihsel anlatılardaki bu düzenin postmodern tarih kuramına göre sahte bir düzen olduğunu ifade eder. Hayden White (1973: 5), Metahistory adlı kitabında “...tarihsel metinler kesin olarak söylemek gerekirse, açık sonludur. Prensip olarak tarihsel metinlerin 'başlangıcı' yoktur; onlar yalnızca, tarihçinin olayları kaydetmesiyle başlar. Ayrıca tarihsel metinlerin sonucu ve çözümü de yoktur" der. Tarihçinin öyküsünü oluşturmak için yapacağı seçimler tarihsel metnin gerçekliğini oluşturacaktır. Gerçekliği, nesnellik ve öznellik sorunsalı içinde sorgulamaya açık tarih, kendi metinsel gerçekliğinde kabul görecektir.

Tarihsel olayların yazılı metinlerle aktarılması, tarihin metinsel oluşunu gösterir. Tüm tarihsel metinler, tıpkı diğer metinler gibi başka metinlerin yorumlanması ve yeniden şekillenmesiyle oluşmuştur. Oppermann (2006: 14), “deg̃işen söylemler ve dil bu metinlerin anlamlarını merkezileştirilemeyen ve sabitlenemeyen olgular olarak ortaya koyar" derken; tarih metinlerinin, tarih söyleminin denetiminde görünseler de anlamlarının bu bağlam içinde bütünselliğinin olmadığını söyler. Bu bağlamda tarih ve edebiyatı birlikte değerlendirme fikrini Yeni Tarihselcilik akımının tanımında ortaya atan Louis Montrose, "tarihin metinselliği ve metnin tarihselliği” formülünde hem yazınsal hem de tarihsel metinlere eşit ağılık verilmesini ve birbirleriyle olan etkileşimlerinin incelenmesini savunur (1989: 15-36).

\section{Nesnenin ve Hareketin Bütünselliḡi}

Montrose'un yazınsal ve tarihsel metnin birlikte değerlendirilmesi fikri, dramatik metinler için de söz konusudur. Tarihsel dram türü, tarihsel gerçeklikten öznel seçimlerine göre kesitler alan oyun yazarının elinde yeniden yorumlanır. Tıpkı tarihsel metinlerin her seferinde bir tarihçinin öznel seçimleri doğrultusunda yeniden yorumlanması gibi. Bu karşılıklı benzeş ilişki ancak, dram yazarı ve tarihçinin malzemeyi nasıl kullandığı noktasında yaklaşım anlamında farklılık göstermektedir. György Lukacs (2008: 112), 'Tarihsel Roman' adlı kitabında, epik (roman) ve dramanın nesnel gerçekliḡin bütünsel görüntüsünü verdiğini dile getirir. Bu özellikleriyle epiğin diğer alt 
türlerinden ayrıldıklarını ifade eden Lukacs (2008: 112), bu farklılığın nicelik ve kapsamla değil, sanatsal üslubun, sanatsal biçimlendirmenin, tasvirin her bir safhasına etki eden niteliksel farklılığı olduğunu belirtir. Lukacs, epik ve dramanın, hayat sürecinin bütünselliğini tasvir etmesi gerektiğini vurgular; Lukacs'a göre bu gereklilik, nesnel gerçekliğin sanatsal olarak yansıtılmasındaki biçimsel yoğunlaşmanın sonucudur. Lukacs hayatın sahici ve sonsuz bütünselliğinin düşünsel olarak ancak görece bir biçimde yeniden üretilebileceḡini söyler. Bu görece, Lukacs'a göre kusurlu bir yeniden üretimdir. Fakat bu kusurlu üretim sanatsal olarak özel bir biçime bürünür. Edebi ya da dramatik olarak tasvir edilmiş bir insanın ayırıcı nitelikleri ve tezahürleri, hayatın sahip olduğu o sonsuz ve tükenmez zenginliğini bünyesinde barındıramaz. Fakat yine de bu kusurlu suretin sanki gerçek hayatmış gibi, hatta daha gelişmiş, daha yoğun, daha canlı bir hayatmış gibi etki etmesi sanatsal biçimlendirme bağlamında zorunludur (Lukacs, 2008:113). Şayet tüm derin duyguları ve coşkularıyla yaşamın bütünselliği dramada eksik kalırsa bunun hiçbir şekilde telafisi olmayacaktır. Insanda ve yazgısında genel olan şeyi özel kılmak sanatsal biçimin görevidir.

Lukacs (2008: 116) ayrıca, Hegel'in epik ve dramanın bütünsellik tasviri üzerinde de durur. Hegel'in Estetik'inde büyük epiğin, dünya tasvirinden, öncelikle 'nesnelerin bütünselliğini' talep ettiğini ifade eder. Toplumsal-tarihsel koşulların nesneleriyle -romanda bulunan kişiler, olaylar ve varlıkların tümü- canlı etkileşimi olmadan insanın sadece iç dünyasını anlatacağı ve sanatsal boşlukta dağılıp gideceği iddiasına da atıfta bulunur. Lukacs'ın üzerinde durduğu bütünsellik'i, drama da bir dramatik çatışma çevresinde talep eder. Dramatik eylemin çatışma halindeki bir eylem üzerine kurulduğunu ve gerçek birliğin temelini ancak bütünsel hareket içinde bulduğunu söyleyen Hegel'e yeniden atıfta bulunan Lukacs, 'hareketin bütünselliḡi' birbiriyle savaşan, çatışma etrafında gruplaşan insanların hissiyatının bu zenginliğinden ve herşeyi kucaklayan bu bütünsellik içinden çıktığını ve karakterlerin bununla birbirlerini karşılıklı olarak tamamlayarak hayatın bu çatışmasının tüm imkanlarını yansıttıklarını söyler (Lukacs, 2008: 116). Bu noktada tarihi, oyununa malzeme yapan yazarların üretim aşaması da şekillenmektedir. Nesnelliğine artık şüpheyle yaklaşılan tarihsel gerçeklik, dramatik malzeme olarak nesnenin bütünselliği'ni temsil ederken, dramatik çatışmaysa hareketin bütünselliği şartını sağlamalıdır. Bu bağlamda yukarıda bahsedilen Montrose'un yazınsal ve tarihsel metnin etkileşim gerekliliği ile nesnenin bütünselliği ve hareketin bütünselliği arasındaki etkileşim gerekliliği birbiriyle ilişkilendirilebilir. Tarihsel metin, nesnenin (kişiler, olaylar ve varlıklar), yazınsal metin ise -burada dramahareketin (dramatik çatışma ve aksiyon), temsili olacaktır.

\section{Tarihsel Bir Karakter Olarak Jeanne d'Arc}

Tarihin nesnelliḡine yönelen şüpheli bakışlar, Jeanne d'Arc gibi Fransa tarihinde dinsel ve askeri yönden oldukça önemli bir karaktere de aynı şüpheyle çevrilecektir. Jeanne d'Arc tarihte yaşamış bir karakter olarak kabul görse de, özellikle XXI. yüzyılda tarih araştırmacıları tarafından gerçekliği sorgulanmıştır (Senzig vd., 2007: 23-201). Bu sorgulama, tarihe olan bakış açısının değişimiyle ilgili midir bilinmez, fakat doğaüstü güçleri olduğu bilinen ve bu yüzden kilise tarafından büyücülük ve cadılık iddialarıyla yargılanan ve ardından yakılarak öldürülen Jeanne'ın gerçek hikayesi doğaüstü olaylara sahne olmuştur. Ayrıca, genç bir kızın böylesi zorlu askeri zaferler elde etmesi gerçekçi bulunmamıştır. Fakat, tüm bu şüphelere karşın Jeanne'ın hayatını ve ölümünü anlatan çok sayıda kaynak bulunmaktadır.

Bu kaynaklarda, Jeanne'ın hayatı tüm ayrıntılarıyla (görgü tanıklarının ifadelerine dayanarak) anlatılmaktadır. Jeanne, 1412'de Fransa'nın Domrémy adlı küçük bir kasabasında doğar. Sıradan, inançlı bir köylü kızı olan Jeanne, kendisine tanrı tarafından Fransa'yı kurtarması için bir takım sesler ve hayaller iletildiğine inanmaktadır. Jeanne, duyduğu bu sesleri ve gördüğü hayalleri kendi hayatı için tanrının bir emri kabul edip, bu seslere olan inancını kiliseye ve devlete olan inancının üzerinde tutarak, kararlı bir şekilde yola koyulur. Fransa veliahtını kendisine at, zırh ve asker vermesi için ikna ederek, o sıralarda işgal altında bulunan Orleans'ı İngilizlerden kurtaran Jeanne Veliahta tacını giydirir ve Charles Fransa kralı olur. Savaş sırasında gösterdiği askeri 
yetenekleriyle askerleri ve halkı kendisine hayran bırakır. Halktan ve askerlerden aldığı destekle Paris'i İngilizlerden kurtarmak üzere yoluna devam eder. Jeanne'nın, basit bir köylü kızı olduğu halde müthiş bir askeri beceriye sahip, iyi yürekli ve dost canlısı olduğu, insanlara huzur veren derin bir ifadesi olduğu anlatılır. Yüzyıl savaşları boyunca İngiltere'ye karşı ülkesini Lorraine cephelerinden başlayarak destekleyen Jeanne, sonunda yenilgiyi kabul edemeyen İngilizler tarafından büyücü olduğu iddia edilerek engizisyon mahkemesine verilir. Aylar süren yargı sürecinin ardından yakılarak öldürülür. Ölümünden 490 yıl sonra Jeanne'nın yakılmasına kararı veren kilise, bakireyi azize ilan eder. Ölümünden önce ve sonra görülen tüm mahkeme kayıtlarının bugün Fransa Milli Kütüphanesinde saklanması Jeanne d'Arc'ın tarihsel gerçekliğinin kanıdı gibi görünse de kayıtların doğruluğu tartışılabilir çünkü İngiliz yargıçların dava boyunca kasıtlı olarak ifadeleri çarpıttıkları Jeanne d'Arc davasıyla ilgili kaynaklarda belirtilmiştir (Sullivan, 1964: 62-85).

\section{Jeanne d'Arc: Yapıntı Karakter}

Jeanne d'Arc, tarihsel bir figür olarak birçok oyun yazarı tarafından kullanılmıştır. Jeanne d'Arc'ın bir halk kahramanı olması ve tarihsel çatışmasının din, devlet ve millet ideolojileri üçgeninde gelişmesi, Jeanne d'Arc ve hayatını bulunmaz bir dramatik malzeme yapmıştır. Bernard Shaw'un Ermiş Jeanne'ı, Bertolt Brecht'in Mezbahaların Kutsal Johanna'sı, Simone Machard'ın Düşleri ve Anna Seghers'in radyo oyunundan uyarladığı Jeanne d'Arc 1431 Rouen Duruşması ve Schiller'in Orléans'lı Bakire adlı oyunu Jeanne d'Arc üzerine yazılmış oyunlardan bazılarıdır. Bu çalışmada tarihsel figürün farklı kullanımlarına örnek olması bakımından tercih edilmiştir.

Bernard Shaw'un Ermiş Jeanne'ı, tarihsel kişiler ve olaylardan yola çıkarak, kilise ve devlet gibi kurumlara eleştirel bir yaklaşım getiren; aynı zamanda her türlü iktidar hırsını mizah yoluyla yeren bir oyundur. Bu sayede oyun, salt olayın geçtiği döneme değil, tüm zamanları kuşatan bir temaya dikkat çekmiştir. Tiyatro yazını içinde dili en ustalıklı kullanan yazarlar arasında yer alan Shaw, bu özelliğini oyunun bütününde sergilemiş, trajik olana mizahi bir tat katarak, dili güldüren bir eleştiriye büründürmüştür.

Ermiş Jeanne'ın malzemesi tarihsel gerçekler olsa da oyun, geleneksel bir tarihsel dram örneği değildir. Bilindiği gibi Shaw, kendine özgü tiyatro şeklini, 19. yüzyılın dram türlerinden (melodram, fars, komedi, pantomim, tarihsel dram ve extravaganza) çarpıtarak gerçekleştirmiştir (Ferlier, 1982: 136). Shaw, kendine has tarzıyla oluşturduğu oyunda, Jeanne d'Arc'ın tarihsel gerçekliğini çıkış noktası yaparken, Fransa ve İngiltere arasındaki anlaşmazlığı ortaya koymuş, bunun arkasındaki kilise ve iktidar çatışmasını da tartışma konusu yapmıştır. Baş kişi Jeanne, karşısında kilise ve devlet vardır. İngiliz komutan Warwick, Piskopos Couchon ve Stogumber (tarihte yaşamış kişiler) üçlü iktidarı temsilen ikincil kişiler olarak kiliseyi ve devleti savunmaktadırlar.

ilber Ortaylı (2010: 157-176), tarihsel oyunların kaba bir tarihsel gerçeklik içinde değil, düşünsel içeriği ve savı yönünden değerlendirmenin önemi vurgulamıştır (Ünlü, 2011: 13'den). Shaw, Jeanne'ın Baudricourt beyinden at ve zırh istemesi, Fransa veliahtı Charles'a Tanrı emriyle taç giydirmek için Reims'e gitmesi, Orléans galibiyeti ve engizisyon davası, tutsaklık süreci ve yakılması gibi belli başlı önemli olayları dramatik malzeme olarak kullanmış, fakat dramatik gerçekliği çatışmanın temelinde değiştirmiştir. Her sahne kendi başına birer dini, siyasi ve ekonomik çatışmayı temsil etmektedir. Bu çatışmalar hem oyuna güncel dayanak oluşturup dramatik akıcılık sağlamakta, hem de ideolojik bir tartışma platformu oluşturmaktadır. Karakterlerin her biri bir ideolojinin temsilcisidir. Bu da oyuna, düşünsel anlamda derinlik getirmektedir.

Jeanne d'Arc tarihsel figür olarak, bilinen kahraman ve öncü kişiliğinden birşey kaybetmemiştir. Yazar, tarihsel gerçeklik boyutunda Jeann'ın duygularını, çoşkularını ve azmini yansıtmıştır. Fakat, Shaw'un Jeanne'ı parlak zekası ve karizmasına rağmen aynı zamanda dik kafalı, kendini beğenmiş ve inatçıdır. Rouen'deki mahkeme salonunda geçen altıncı sahnede engizisyon yargıcı Jeanne'nın mahkemeye verdiği cevaplar sonrasında diğer yargıca "Ağzını her açışta kendini on kere ölüme mahkum ediyor" (Shaw, 1967: 292) der. Jeanne, oyundaki özellikleriyle etkili, güçlü ve çağdaş bir karakterdir fakat milleti için Tanrı adına 
savaşırken, kendini beğenmiş ve boyun eğmeyen tavrı onu ateşe götürmektedir. Uğruna savaştığı yüce değerler, amacına giden yolda Jeanne'ı yalnız bırakır. Oyun, tarihsel olaylardan hareketle, sisteme getirilen bir eleştiri olarak okunabilir. Jeanne, din, devlet, millet ideolojisi üçlemesi karşısında tek başına bir çatışan gibi gözükse de, aslında henüz kimliğini bulamayan Fransız halkının da temsilidir. Öte yandan Jeanne'ın yakılarak öldürülmesi zaten kilisenin halka verdiği bir göz dağıdır. Jeanne, halkın önünde ateşe atıldığında, izleyenlerin özgür iradesine zincir vurulmuş olacaktır. Böylece kilise ve devletin halk üzerindeki etkisi değişmeyecektir. Fakat, aksine, Jeanne d'Arc yakıldıktan sonra ibret deḡil halk ve askerler için ilham kaynağı olmuştur.

Ermiş Jeanne, Jeanne d'Arc'ın tarihsel hikayesini yansıtması yanında, yaşamın içinde olan gerçek çatışmayı başarıyla yansıtmıştır. İdeoloji, muğlak güç ve insanın kırılganlığı karakterlerde başarıyla işlenmiştir. Toplumsaltarihsel koşullarıyla uyumlu dramatik çatışma, oyunun belkemiğini oluşturmuştur. Epilog kısmında Shaw (1992: 330), okuyucuyu geleceğe doğru zamanda yolculuğa çıkarır. Yirmi beş yıl sonra Charles'a bir rüyada Jeanne ile yüzleşme imkanı vermesi oyunun sonunu ilginç hale getirmektedir. Burada Jeanne'ın yakılmasına karar veren savcı Ladvenu, Couchon, Dunois ve Jeanne alevler içinde yanarken, ona tahtalardan haç yapıp veren İngiliz askeri görülmektedir. Hepsi de Jeanne'a yaptıkları yüzünden pişmandır ve sırayla günah çıkartırlar. Okuyucu, insanların tarihten ve olanlardan ders çıkarabileceği fikrine kapılsa da, sonunda aslında kimsenin deḡişmediğini ve tarihin tekerrürden ibaret olduğunu anlayacaktır. Jeanne, herkesi, tekrar hayata dönmekle ilgili yokladığında, ortada kimsenin kalmadığını, hatta uğruna canından olduğu Charles'ın bile uykuya dalarak Jeanne'ı terk ettiği görülür. Oyun, Jeanne'ın 'Şu güzelim dünyayı yaratan Tanrım. Senin ermişlerine dünya ne zaman kucak açmayı öğrenecek? Ne zaman Ulu tanrım,ne zaman?" (Shaw, 1992: 330) diyerek serzenişte bulunmasıyla sona erer.

Kendi Saint Joan'unu yaratırken Ermiş Jeanne' dan etkilenen Bertolt Brecht, 1926 yılında yayımladığı yazısında (Brecht, 1986: 10), Shaw'u, "olağanüstü bir silah, mizah silahı kullanan" ve seyircisine düşünsel saldırılar yapan "bir terörist" diye niteliyor ve "terör ünün" özelliklerini araştırıyordu . Brecht'e göre Shaw'un terörü her insanın dürüst, mantıklı bir biçimde ve bir mizah anlayışı ile hareket etme yetkisini elinde bulundurduğu ve kendisine karşı çıkılsa bile bu biçimde hareket etmek zorunda olduğu noktası üzerinde ısrarla durmasından kaynaklanmaktadır (Ferlier, 1982: 106, 107). Düşünsel saldırıdan bahsederken, Shaw'un, Ermiş Jeanne'ında belirgin olarak görülen, düşüncelerden gelen çatışmayı nitelemektedir aslında. Kişiler deḡil düşünceler çatışmaktadır. Oyundaki tarihsel figürler temsil ettikleri ideolojiyi kararlılıkla savunurken, Shaw'ın hedeflediği çatışmaya hizmet etmiştir. Gelişimleri, düşüncelerine paralel olarak gerçekleşmiş ve sonuçlanmıştır. Brecht, "oyun kişilerinin yazgısı, taşıdıkları düşüncelerle özdeştir” (Ferlier, 1982: 107) derken tam da bundan bahsetmiştir. Klasik trajedideki yazgı, bu oyunda olaylarla deḡil düşüncelerle örülmüştür. Jeanne d'Arc'ın tarihsel gerçekliğinde derinine inilmeyen insani özelliklerini ön plana çıkarmış; Jeanne'ı, hareketlerini yönlendiren inanç ve düşünceleri ile resmetmiş ve onun dramatik bir karakter olarak var olmasını sağlamıştır.

Bertolt Brecht'in 1929-1930 yılları arasında kaleme aldığı Mezbahaların Kutsal Johanna'sı adlı oyunda, tarihsel kahraman Jeanne d'Arc, Brecht tarafindan yeniden yaratılmıştır. Brecht, oyun yazarı olarak daha yirmili yılların ortalarında, hem kapitalist ekonomide gelişen olaylarla ve borsa spekülasyonlarıyla, hem de o olaylar içinde beliren geç burjuva toplum düzeniyle ilgilenmeye başlamıştı. Cihat ordusu ile onun kapitalist sömürünün nedenlerini örtbas edici sosyal yardım eylemleriyle, dinci propoganda seferleriyle de ilgilenmekteydi. 1929 yılında Brecht, kapitalist pazar mekanizmasının etkileri ile sömürü sisteminin işleyişini ve cihat ordusunun eylemlerini tek bir dramatik öyküde, -fragman olarak kalan- Ekmekçi Dükkanı oyununda birleştirmeyi denemişti. Brecht, Mezbahaların Kutsal Johanna'sı için edebi ve edebiyat dışı kaynaklar ${ }^{2}$ kullanmıştır. Bunların hiçbiri öyküyü belirleyici olmamışsa da, oyundaki pek çok gerçeği, pek çok motifi bu kaynaklar sağlamış, yapı ve üslup üzerinde etkili olmuştur (Brecht, 1999: 254). 
Oyun, Almanya'nın 1932 yılında geçirdiği büyük ekonomikbunalımıtemsilen, Chicago'dakietmezbahalarında geçmektedir. Oyun, o dönemin ekonomisine ve kapitalist sistemin işleyişine getirilen bir eleştiridir. Sistemin ne olursa olsun, varlığını sürdüreceği ve kendine bir kurban seçeceği anlatılmaktadır. Oyun, Pierpont Mauler adlı et kralı ve iş yaptığı et fabrikatörleri, Cridle, Grahami Lennox ve Meyers arasındaki amansız çıkar mücadelesini ile karşılarında yer alan işçi ve yoksul sınıf arasındaki çatışmadan beslenir. Jeanne d'Arc, Kara Hasırşapkalılar adlı Evangelist bir kuruluşun üyesidir. Johanna, düzenin farkında olmayan ve dünyasal zevklerin Tanrı sevgisi yanında bir hiç olduğuna inanan yirmi beş yaşında genç bir kadındır. Lider Johanna karakteri, mezbahalarda çalışan yoksul işçilerin sorunlarını iyilik ve Tanrı inancıyla azaltmaya çalışır. Oyun, Johanna’nın bilincinin, Mauler'in ise ekonomik güçlere ve içindeki insani duygulara karşı savaşının büyümesi ile gelişir. Sonunda Mauler düzene yenilse de, Johanna'daki iyiliği görür; Johanna ise sistemi anlamakta, onu düzeltmek için elinden bir şey gelmediğini görüp isyan ederek hayata veda eder.

Piyasada et kralı olarak anılan Mauler, yoksulun halini düşünmemekte, onlardan korkmaktadır. Yoksulların aç kaldıklarında her türlü kötülüğü yapacağına inanan Mauler aracılığıyla Brecht'in, yoksulları bu şekilde tanımlaması sebepsiz deḡildir. Brecht'in gençlik dünyasında, yoksullar aşağılık, zenginler acımasız ve sömürgendi. Yazarın oyunlarında tekrar tekrar üzerinde durduğu nokta, acı çeken yoksulun, yarın bir olanakla yükselme fırsatı elde ettiḡinde bu düzen (kapitalist burjuva) içinde, ezenler kadar obur, acımasız olacağıdır (Nutku: 2007, 36).

Johanna ise işsizler için verdiği mücadele ve cesaretiyle anarşist bir karakterdir. İşçileri ve yoksulları mücadelelerinden korkmamaları için yüreklendirir. Ayrıca dinsel inancının gücüyle dikkat çekmektedir. Tanrının adını ağzından hiç düşürmeden mücadele verir. Kapitalist patronların, yoksulları yok sayarak kendi çıkarlarını düşünmelerine şiddetle tepki gösterip, Tanrı'nın bunun hesabını soracağını söyler. Tıpkı Jeanne d’Arc gibi inançlı ve cesurdur.
Brecht'in, Mezbahaların Kutsal Johanna'sı adlı oyunu, birbirinden belirgin şekilde ayrılan tiyatro oyunlarının üç döneminden ikincisi içinde yer almaktadır. Didaktik oyunlar olarak anılan, ikinci dönemine ait olan bu oyununda Brecht, öğreti amaçlarını, daha somut bir tiyatral olay akışıyla ve bir kişinin yazgısının sergilenişiyle birleştirmiştir. Ancak, elbette ki burada da kişi, yine genel'in bir örneği olarak seçilip işlenmiştir. Bir çeşit "bilgilenme-bulguya varma oyunu" yoluyla bilimsel toplumcu ögretinin bir özetini vermektedir (Kesting, 1985: 87).

Brecht'in, Jeanne d'Arc gibi daha çok dini duyguları ve cesareti ile tarihe adını yazdıran bir kahramanı, böylesi bir sınıf mücadelesine koyması şaşırtıcı değildir. Dini grup lideri Johanna' yı sonunda bir proleter kahramana dönüştürür (Kesting: 1985, 87). Başta hiçbir şeyin farkında olmayan kahraman, gittikçe değişmekte, sınıf kavgasına katılmaktadır. Kavgası sürerken her şeyi daha net görmeye başlar; sonunda paranın tek efendi olduğunu görür.

Jeanne d'Arc bu oyunda, tarihsel gerçeklikteki değişim yaratma gücünün izlerini taşır. Brecht'in, "Dünyayı değiştirin, çünkü değiştirmek gerekiyor," şeklindeki görüşü Johanna karakterinin de temel hatlarını oluşturur. Yazarın, iki yüzlülüğe, adaletsizliğe, insan ruhunun karmaşasına olan başkaldırısı, Johanna karakterinde yeniden ayaklanmıştır. Fakat Johanna yine de başarılı olamamış gibidir.

Birşeyi öğrendim, biliyorum sizin için

Bu öğrendiğimin

Ne anlama geldiğini, kendim ölürken: Sizin de İçinizde o şey, ama çıkamıyor açığa! Bir sonuca gitmeyen

Bilgiyi, bilmek mi sanıyorsunuz?

Ben, örneḡin, hiçbir şey yapmış değilim.

Çünkü iyi sayılmaz hiçbir yapılan, görüyorum evet her zamanki gibi,

Gerçekten insana yarayandan başka ve şerefli sayılmaz hiçbiri

Bu dünyayı gerçekten değiştiremiyorsa: Dünya buna muhtaç! 
Ezenlerin imdadına yetiştim sanki!

Ah sonuçsuz iyilik! Kimseye ulaşmamış düşünce!

Hiçbir şey değişmedi işte. Verimsizce ayrılırken bu dünyadan hızla

Bir diyeceğim var:

Dünyadan yalnızca iyi bir insan olarak

Ayrılmayın, yetmez, ardınızda

İyi bir dünya bırakmaya bakın! (Brecht, 1999: 94-95)

Brecht'in Jeanne d'Arc'in tarihsel gerçekliğinden esinlenerek yazdığı tek oyun Mezbahaların Kutsal Johanna'sı değildir. Yazarın 1941-43 yılları arasında kaleme aldığı Simone Machard'ın Düşleri (Die Gesichte ${ }^{3}$ der Simone Machard), 1940 yılında II. Dünya savaşı sürerken, Fransa'da Alman işgalleri sırasında, bir Fransız konukevi sahibi ve Almanlar arasındaki çıkar ilişkilerini anlatmaktadır. Brecht, Mezbahaların Kutsal Johanna'sı oyunundaki gibi tarihsel Jeanne d'Arc karakterinin yerine bu kez Simone adlı genç bir hizmetçi kızı koymuştur. Simone, sadece gördüğü düşlerde Jeanne d'Arc rolündedir. Konukevinde Mösyö Soupeau, Simone'ye okuması için Jeanne d'Arc'ı anlatan bir kitap vermiştir. Brecht, bu hikayeden etkilenen Simone'nin düşlerinde Jeanne d'Arc'in tarihsel öyküsünü, Simone ve diğer karakterler aracılığı ile yansıtır.

Fakat, Brecht'in Simone Machard'ın Düşlerini yazarken Jeanne d'Arc'la ilgili tarihsel kaynaklara başvurmadığı bilinmektedir. (Tarihsel yazına başvurduğu tek oyun Anna Seghers'in radyo oyunundan uyarladığı Jeanne d'Arc 1431 Rouen Duruşması adlı oyundur). 'Simone Machard' ise, en küçük ayrıntısına kadar, 1940 yazında, 10 Mayıs'ta Alman saldırısıyla başlayan savaşın çağdaş sunumunu içerir. 14 Haziran'da, Paris, savaşılmadan Almanlar tarafından işgal edilir. Fransız hükümeti Bordeaux'ya taşınır. Kabinesinin çoğunluğu silah bırakma anlaşmasından yana olduğu için Başbakan Paul Reynaud istifa eder ve yerine geçen Mareşal Philippe Pétain, bürokratik ve otoriter bir rejim kurarak içte "Vatan, Aile, Çalışma” sloganıyla sözde ulusal devrimi gerçekleştireceği propogandasını yaparken Alman işgalcilerle işbirliği yapar. Oyunun olay dizisi -Paris'in işgal tarihi olan 14 Haziran gecesi başlar ve silahları bırakma anlaşması ile son bulur- çağdaş tarihsel gelişimin altını çizer (Brecht, 2000: 338,339).

Simone Machard'ın Düşleri oyununda, olayın tek bir yerde ve zamanda geçmesine karşın, tarihsel gerçekleri dramatik gerçeklikle benzeştirmek için düş sahneleri kullanılmıştır. Özdemir Nutku (2007: 297), 'Bertolt Brecht ve Epik Tiyatro' adlı kitabında oyunun bütünlüğü olan, tek olay dizisi ile gelişen ve 'epik' öḡelerin müdahalesi olmadan sonlanan bir yapıt olduğunu söylerken; Marianne Kesting (1985: 96), düşler ve hayaller, müzikle olsun, panoların saydamlaşmasıyla olsun, gerçek olay sahnelerinden kesinlikle ayrılır ve her şeyiyle, düş olduğu açık seçik belli edilir diyerek oyunun epik özellikler taşıdığını savunmaktadır. Sahnelere, Kitap, El Sıkışma, Ateş ve Mahkeme olarak verilen isimler, Simone'nin ve Jeanne d'Arc'ın hayat evreleri olarak görülebilmektedir. Kesting (1985: 96), bu sahneleri Simone'nin yolundaki zorlu duraklar olarak tanımlamaktadır.

Brecht (2000: 339), olay dizisinin ayrıntıları ve karakterlerin niteliklerini Almanların 1940 yazında Fransáyı işgal ettikleri dönemdeki olayları ve kişileri yansıtmaktadır. Yalnızca düş sahnelerinde karakterleri Jeanne d'Arc hikayesinin tarihsel figürlerine dönüştürmüştür. Saint Martin Belediye Başkanı Philip Chavez düşlerde VII. Charles; şarap tüccarı Honoré Fetain, Burgonya Dükü; konukevinin sahibi Henri Soupeau, başkomutan; annesi Marie Soupeau, Charles'ın annesi İsabeau; bir Albay, Beauvais Piskoposu; Alman Yüzbaşı, İngiliz komutan ve son olarak Simone, Orléans'lı bakire Jeanne d’Arc olarak karşımıza çıkar.

Simone Machard'ın Düşleri'nde amaç Jeanne d'Arc'ın kahramanlık öyküsünü anlatmak deḡildir. Brecht, her şeyden önce, halkın yurttaşlık konusunda bilinçsiz oluşunu ve herkesin her durumda kendi çıkarını gözettiğine vurgu yapmıştır. Savaş ülkeyi yiyip bitirirken, Fransız sermaye sınıfı, ticari çıkar uğruna, Nazilerle işbirliğine girip, ulusal direnişi baltalamaktadır (Kesting:1985, 96). Halk, kendini kurtarmaktan başka bir şey düşünmemektedir.

Aslında Simone'nin büründüğüJeanne d’Arc karakterinin 
eyleminin kaynağı, cesaretinden çok duygularından gelmektedir. Simone'yi harekete geçiren ilk olay, göçmen işgalinin, birliklerin ilerlemesine engel olmasıdır. Çünkü birlikte kardeşi André de vardır. Daha sonra tepkisiz halkı hareketlendirecek olan Simone, aslında sermaye ve Naziler arasındaki kirli ilişkiyi net olarak görememektedir. Sadece, Almanlar elleri boş dönsün diye çaba harcamaktadır. Bu noktada Simone'nin gerçekten düzende ihtiyaç duyulan çözümü doğru yerde aradığı şüphelidir. Güçlüler karşısında savaşmış fakat yenilmiştir.

Brecht'in bu iki oyununun aksine tarihsel gerçekliğe birebir uygunluk gösteren hatta tarihsel belge niteliği taşıyan bir başka oyun ise Anna Seghers'in 1933-37 yılları arasında araştırmalarını yapıp, kaleme aldığı ve Bertolt Brecht'in 1952-53 yıllarında sahneye uyarladığı Jeanne d'Arc 1431 Rouen Duruşması, (Der Prozess des Jeanne d'Arc zu Rouen 1437) adlı radyo oyunudur. Oyun, Paris Milletvekili Meclisi'nde bulunan Fransızca ve Latince olarak kaydedilen duruşma tutanaklarından faydalanarak yazılmıştır. Seghers'in radyo oyunu, bu tutanaklara olduğu kadar, tanıkların görüşlerine ve açıklamalarına da dayanmaktadır. Seghers'in oyunu, Jeanne d'Arc'in dava sürecini ve Ortaçağ yargı mekanizmasını yansıtırken, aynı zamanda, halkın dava süreci içindeki gelişimini de anlatmaktadır. Anna Seghers, Paris'teki sürgün yıllarında, bu tarihsel figürün hayatını kendi hayatıyla özdeşleştirmiştir (Wallace, 1998: 76).

Seghers'e göre, Jeanne hakkında ilgi çekici olan şey onun, kökleri halkta olan bir kahraman olmasıdır (Bangarter, 1980: 99'dan). Seghers'in arkadaş ve çağdaşı Brecht, 195253 yılları arasında sahneye uyarladığı oyuna, kendisine ait ortalama yirmi beş parça yeni öğe eklemiştir (Wallace, 1998: 78). Fakat, Brecht'in eklediği bu parçaların hangileri olduğu tam olarak bilinmemektedir. Bu çalışmada Seghers'in metni referans alınmıştır.

Oyun, Jeanne d'Arc oyunları arasında, tarihsel gerçekliḡin öteki yüzünü de ele alan tek oyundur. Jeanne d'Arc'ın duruşması, Fransız Milli Kütüphanesinde saklanan belgelerden birebir (Jules Quicherat'nın Jeanne d'Arc'ın yargılanmasını içeren 1431 ve 1456 dosyaları) aktarılırken, diğer tarafta, halkın kahramana bakış açısı işlenmiştir. Dava boyunca halk, ülkenin siyasi ve dini durumuna göndermeler yaparak, Jeanne'ın dava sürecinin tarihsel gerçeğini de gözler önüne sermektedir.

Seghers, Jeanne d'Arc davasına benzer davalarla özel olarak ilgilenmiştir. Hatta 1934 yılında, oyunu yazmaya hazırlandığı dönemde Avusturya'da, antifaşist başkaldırıya dahil olan sosyalistlerin davasına katılmıştır. Seghers'e göre adaletsizlik, terör ve kör dogma zulmün ana unsurlarıdır. Bunlardan ilki olan adaletsizliğin, medeni toplumların geleneksel olarak ahlaki kodlarını belirleyip dayattıkları resmi süreçler olan dava, mahkeme ve bu süreçleri yönetenlerin mercek altına alınmasıyla altı çizilebilecektir (Wallace, 1998: 82). Bu yolla Seghers, bir anlamda kendi dini dogmalarını halka dayatan ve onları korkutarak boyun eğdiren Ortaçağ yargı mekanizmasını da eleştirmektedir. Dava sürecini, olduğu gibi göstererek, okuyucuya, objektif bir deḡerlendirme şansı vermektedir. Oyunda, Jeanne d'Arc davasının, özellikle kişisel özgürlük ve seçimlere saldıran bölümleri ön plana çıkmaktadır. Seghers bunu, tarihsel gerçekleri kullanarak yapmaktadır. Birincisi, Schiller'e özgü olan özgür Jeanne d’Arc'ı (Orléans'lı Bakire) zincire vurulmuş, gardiyanların eşliğinde göstermekte, ikinci olarak da 14311456 yılları arasındaki dava kayıtlarını, davanın haksızlığını ve kör dogmaları göz önüne koyabilmek için, onlara tamamen sadık kalarak yansıtmaktadır.

Jeanne d'Arc 1431 Rouen Duruşması, hem tarihsel, hem de toplumsal perspektifler içermektedir. Olayların odak noktasını genç Bakire'den öteye çevirmek ve onun yarattığı etkileri göstermek için, halk kullanılmıştır. Eğer oyun -toplumsal bir belge- olarak halkın devrim niteliğindeki potansiyelini göstermekteyse -feminist bir belge- olarak da kadın başkişisini devrimci bir başarıyla ödüllendirmektedir (Wallace, 1998: 88). Jeanne'ın görevine ve inancına çağının ötesinde bir tavırla sarılması; ve bu inancın halkın içindeki gücü ayag̃a kaldırması bunun kanıtıdır. Mahkeme, Jeanne'ın gerek insan gerekse bir engizisyon sanığı olarak özgürlüklerini elinden almıştır. Jeanne ise kaybettiği özgürlüğü, sonuna kadar halkı için direnen bir devrimci gibi halkına hediye etmiştir. Ayrıca erkeklerin hakim olduğu bir düzende, kaderi önceden belirlenmiş bir kadın olarak kendine olan inancını 
korumuştur. Kendi inandıkları, kendisi için kişisel hak olarak gördüg̈ü her şey için ayakta kalmayı denemiştir.

Kısaca Seghers, Jeanne d'Arc 1431 Rouen Duruşması'nda, (Der Prozess des Jeanne d'Arc zu Rouen 1431) kendi hayatının Jeanne ile benzerlikleri üzerinden yola çıkmış, onun yargılanışını ve halkla olan bağını ortaya koymuştur. Bunun yanısıra oyunu, işkence ve inanç; zorbalık ve özgürlük; dünyevi ve ruhani; ayrıca baskı ve adalet gibi karşıtıklarla kuvvetlendirmiştir (Wallace, 1998: 89). Bu bağlamda, Ingilizlerin hegemonyasındaki, Fransız toplumunun yurtsuzluğunu ve Jeanne'ın bu durumu, kendini ateşe atarak nasıl değiştirdiḡini göstermiştir.

Oyun yazarının tarihsel figür ve gerçekliğiyle kurduğu ilişkileri birçok yönden açığa çıkaran oyunların içinde estetik özellikleri ile farklılaşan bir başka oyun ise Frederich Schiller'in Orléans Bakiresi adlı oyunudur. Yüzyıl savaşlarında İngilizlere karşı savaşan Jeanne d'Arc'ın tarihsel gerçekliğinden esinlenilerek yazılan oyunda Jeanne'ın, Tanrı́nın isteḡi üzerine ailesini terk etmesi, erkek kıyafetleri giyip Orléans'ı kurtarması ve ardından VII. Charles'a taç giydirmesi gibi belirgin tarihsel olaylar, oyuna malzeme olsa da, Schiller'in 'romantik trajedi' olarak adlandırdığı Orléans Bakiresi, Jeanne d'Arc'ın tarihsel gerçekliğine tamamen sadık kalınarak yazılmış bir oyun değildir. Oyun, Jeanne d'Arc'ın hayatının romantik bir sunumudur. Görev ve aşkı arasında kalan Jeanne'nın güçlerini kaybetmesi ve vicdanı yüzünden iç çelişki yaşaması oyunun merkezinde yer almaktadır. Tanrısal olanla insani olan arasındaki çatışma aksiyona yön vermektedir. Schiller, oyunun başından sonuna kadar, tarihsel olayları kendi bakış açısıyla yeni baştan yaratmaktadır. Tanrısal olan, insani olanla çatışmaktadır. Karşılaştığı kara şövalye bir çeşit uyarı gibidir. Jeanne, uyarıları görmezden gelerek sonunu hazırlamaktadır.

Illber Ortaylı (1978: 22), 'Tiyatroda Tarihi Oyunlar Üzerine Bir Analiz Denemesi' adlı yazısında, Schiller'in Orléans Bakiresi adlı oyununda, "Jeanne d'Arc, mistik bir itinin değil, bireysel özgürlükle görev duygusunun itisi altında hakiki "Ben'e, benliğe kavuşmaktadır. Böylece, Orléans Bakiresi Schiller'in bireysel özgürlük ve toplumsal görev duygularını sergilediği bir eserdir" der. Oyunda ayrıca, vatanseverlik ve özgürlüğün iki ana motif olduğunu ifade eder. Romantik akımın özgürlük yanlısı tavrı Jeanne'ın bir erkeğe aşık olmasında görülmekteyken, onu çağıran görevi ise, temel çatışmayı oluşturmaktadır. Tanrısal olan, insani olanla çatışmaktadır. Jeanne d’Arc, oyunda doğaüstü bir varlık olarak gösterilirken, Bernard Shaw Jeanne'ın kesinlikle ulaşılabilir olduğunu söylemekle kalmayıp, Schiller'i Jeanne d’Arc ya da yeryüzündeki herhangi bir kadınla en ufak bir bağlantısı olmayan sığ bir karakter yaratmakla suçlamıştır. Ayrıca Jeanne'ın yeni yetme bir Protestan ve milliyetçi olduğunu da belirtmiştir (Sharpe, 1982: 128). Schiller And the Historical Character adlı eserinde Lesley Sharpe (2008: 128), Shaw'un bu düşüncesine katılmakta, Schiller'in tarihsel olarak dönemin politik ve ekonomik olaylarını yansıtmak yerine, zamanının kara büyü, cadı inancı gibi batı inançlarını vurgulayıp, fırtına ve şimşek gibi öğeler kullanarak büyülü bir atmosfer yaratıp, doğa ve doğa üstünü harmanladığını ifade etmektedir. Schiller'in bunu yapmasının arkasında romantik bir tavır yatmaktadır. Romantiklerin ortaçağ değerlerine verdiği önem Schiller'in oyununda kendisini göstermektedir. Sevda Şener (2008: 156, 157), Dünden Bugüne Tiyatro Düşüncesi adlı eserinde, Romantiklerle ilgili şunları söyler: "Çağdaş yazarlar, oyunlarında tüyler ürpertici biçimlerden, düşsel varlıklardan, hayaletlerden, hortlaklardan kokmamakta, dinsel ve arı ruhu, hayvansal gövdeyle birlikte düşünebilmekte, tutkuları, ikiyüzlülükleri, yalancılıkları dile getirebilmektedirler". Jeanne'ın oyunda iki kez karşılaştığı kara zırhlı şövalye, fizikötesi bir varlıktır. Jeanne d'Arc'ın gerçek öyküsünde duyduğu Tanrısal seslerin bir çeşit yansımasıdır. Fakat, gerçek seslerin aksine şövalye, Jeanne'ı görevini bırakması için uyarmaktadır. Savaş alanlarında, Jeanne yalnızken birdenbire ortaya çıkan bu şövalye, korkutucu ve bilinmezdir. Jeanne, ona karşı koymaya kalktığında Jeanne'ı tek hareketi ile durdurur. Gücüne karşı koymak imkansızdır.

Schiller, tarihsel gerçekliğini anlatmayı seçmek yerine, Jeanne d'Arc'ta bulunan daha yüksek bir gerçeği bulup çıkarmıştır. Bu insanın ta kendisi, iç güdüleri ve kendi içinde yaşadığı çatışmalardır. Yazar Jeanne'ın tarihsel gerçekliğini bir trajedi olarak yeniden anlatırken; gerçek 
Jeanne'dan doğacak ve günah keçisine dönüştürülebilecek yeni bir Jeanne keşfetmiştir. Schiller, Jeanne'ı Hristiyan olmaktan uzaklaştırmış, içsel bölünme ve suçluluk duyan, ölüme gerçekte olduğunun aksine suskunluğu ile giden bir kahramana dönüştürmüştür. Tarihsel bir figürün, gerçeḡinden bu denli uzaklaştırılması, estetik amaçlarla da olsa tarihsel dramdan beklenen etkiyi verememektedir. Duygusal manada evrensel olarak kabul edilse de asıl hikayeyi anlatmak konusunda geride kalmaktadır. Bu da tarihsel gerçeklik ve dram dengesinin ne kadar hassas olduğunu açıkça ortaya koymaktadır.

\section{Sonuç}

Yakılmadan önce engizisyon yargıçlarına, "beni Tanrı gönderdi; burada işim yok; beni geldiğim yere, Tanrıya geri gönderin' (Michelet, 1957: 76) demişti Jeanne mahkemede. Bu kadar çok seviyordu Tanrı'sını ve inanıyordu ona. Denis Léon (1923: 390) onun için, "Fransa binlerce yiğit askere ve mert ustalara sahip oldu; Jeanne d'Arc gibisine asla!" diyerek Bakire'yi onurlandırmıştır. Jeanne d'Arc, Tanrısını ve Fransa'yı herşeyden çok seven sade bir köylü kızıdır. Tanrıdan ve meleklerden sesler duyduğuna yürekten inanarak Fransa’yı kurtarmak için yola çıkar. Başta Orléans zaferi olmak üzere birçok askeri zafere imza atar. Fransa kralına Reims'de taç giydirir ve sonunda büyücülük gibi ağır bir suçla çok sevdiği ve uğruna savaştığı Fransız halkının önünde yakılarak can verir. Ölümünden neredeyse beşyüz yıl sonra ironik bir biçimde azize ilan edilir. Tarihsel metinlerde karakteri ve hayatıyla ilgili sayısız bilgi ve belge bulunan Jeanne tarihsel bir figüre, dini bir ikona dönüşür.

Jeanne d'Arc'ın trajik kahramanlık hikayesi özellikle azizelik ünvanı verildikten sonra Bernard Shaw, Bertolt Brecht (üç kez), Anna Seghers ve Frederich Schiller gibi oyun yazarları için ilham kaynağı olmuştur. Tarihsel gerçekliğin nesnelliğinin sorgulanmaya başlayıp Yeni Tarihselcilik'in bir eleştiri yöntemi olarak sahneye çıktığı 19. yüzyılda, tarihin metinselliği, metnin tarihselliği tartışılmaya başlanmıştır. Tarihsel ve yazınsal metin anlayışındaki değişim okuyucunun metne yaklaşımı kadar drama ve edebiyat yazarlarının da tarihsel metne yaklaşımını değiştirmiştir. Nesnelliği sorgulanan tarihsel gerçeklik, oyun yazarı için, tarihi belgelerden aktarılan kronolojik bilgilerden çok, olayların ve tarihsel figürün ilham kaynağına dönüştüğü yorumlara evrilmiştir.

Değişen tarih algısı ve tarihsel metinlere bakış, tarihsel malzemenin farklı yazarlar tarafından yeniden yorumlandığı Ermiş Jeanne (Shaw), Mezbahaların Kutsal Johanna'sı, Simone Machard'ın Düşleri (Brecht), Jeanne d'Arc 1431 Rouen Duruşması (Seghers), ve Orléans'lı Bakire (Schiller) adlı oyunlarda görülmektedir. Tarihsel gerçekliğin nesnelliğinden emin olamıyorsak tarihsel bir olayı ya da figürü ele alan bir oyunun tamamen tarihsel gerçeklerle bağlı olması da beklenemeyecektir. Olması gereken, yazarın tarihsel gerçeklikten ilham alarak kendi gününe eleştiride bulunmasıdır. Yukarıda incelenen oyunların neredeyse hiçbiri tarihsel gerçekliği geleneksel tarihsel drama uygun olarak ele almamıştır. Ayrıca tarihsel gerçeklik, malzeme olarak romanda olduğu gibi kronolojik, birebir ve derinlemesine de ele alınmamıştır. Lukacs'ın hareketin bütünselliği bağlamında oyunlar, temel çatışma ve aksiyon etrafında temellenmiş̧ir. Nesne (oyun kişisi, mekan, olaylar) değil hareket ön plana çıkmıştır.

Bernard Shaw Ermiş Jeanne'da tarihsel gerçeklere kronolojik olarak sadık kalmış fakat Jeanne d'Arc'ın karakterini komiğe yaklaştırarak sivriltmiştir. Jeanne'ın azize ilan edilmesinden sonra yazılan oyunda çatışma din ve devlet ideolojisi üzerine kurulmuş eleştirel bir oyundur. Jeanne'ın oldukça dik kafalı, inatçı ve kendini beğenmiş bir karakter olarak çizilmesi ve Epilog sahnesiyle daha yenilikçi bir tarih anlayışının hakim olduğu Ermiş Jeanne, klasik trajedideki kişisel yazgıyı, insanın yazıııını göstermek için kullanmıştır. Brecht'in Mezbahaların Kutsal Johanna'sı, Simone Machard'ın Düşleri oyunlarında yaratılan yapıntı Jeanne'lar ciddi bir sınıf mücadelesi ve çıkar çatışmasının ortasına bırakılmasına rağmen, gerektiği şekilde davranmakta geciken karakterler olarak görünürler. Brecht insanın yaşamını ve yazgııını yine klasik trajedinin aksine günümüz kapitalist düzenine yakın koşullara göre belirlemektedir. Fakat çıkarların ve metaların geçerli olduğu bu dünyalarda kahraman olarak Johanna ve Simone'nin sistemin gerçeklerini ve gerekliliklerini geç kavraması ve 
esas çözüme yönelik davranamayıp pasif kalmaları onları bu yönleriyle anti-kahramana yaklaştırmıştır. Seghers, kendi hayatıyla özdeştirdiği Jeanne d'Arc'ın tarihsel gerçekliğini yeterince ilginç bulup, herhangi bir deḡişikliḡe gitmeksizin Jeanne'nın hikayesini tüm çıplaklığıyla aktarmıştır. Jeanne'la birlikte halkın gücünü de ortaya koymuştur. Schiller ise Orléans'lı Bakire'sinde tamamen farklı romantik bir Jeanne yaratmıştır. Schiller'in bambaşka bir estetik anlayışla yarattığı Jeanne, tarihsel bir figür olarak tarihsel gerçekliğin oldukça uzağındadır. Fakat burada yazarın yaşadığı dönem ve sanat anlayışından yola çıkıldığında Jeanne d'arc'ın yazarda oluşturduğu duyguların daha derin, coşkulu ve romantik olması beklenmedik olmayacaktır. Romantik bir estetik anlayışın oyun kişisinde trajediye özgü bir ıstıraba dönüşmesi anlaşılabilir olmaktadır. Duyguları ve görevi arasında kalan bir Jeanne d'arc belki de tarihsel gerçekliğine kıyasla daha özgür, kendi duygularına görevini unutacak kadar kulak veren bir kadındır. Bu da onu Shaw'un ifade ettiği gibi sığ deg̃il aksine daha derinlikli bir karaktere dönüştürmektedir.

Jeanne d'Arc tarihsel bir figür olarak, dramatik malzemeye dönüşmüştür. Tarihsel malzemenin deḡişik biçimlerde yorumlanması oyunlara çağdaş bir duruş getirmiştir. Oyun yazarının tarihin gerçeklerine kayıtsız kalmayıp bu gerçekleri kendi sözü için başka bir boyuta taşıması, dramadan beklenen toplumsal ve tarihsel bağları kurmuştur. Tarihsel figürde olması gerektiğini düşündüğümüz özellikler bir klasik kahramandan beklediḡimiz şekilde kurgulanmamıştır. Yine de yaratılan tüm Jeanne d'Arc karakterlerinin kendilerine has dramatik güçleri dikkat çekicidir. Oyunların merkezinde bulunan toplumsal-tarihsel yönü kuvvetli çatışmaları, insani yönleri eksiksiz kişiler olarak tamamlamış, tarihsel gerçekliği sanatın estetik gerçekliğiyle yüceltmişlerdir.

\section{Notlar}

1 Bu konuda detaylı bilgi için bkz.: Sullivan, Karen (1964). The Interrogation of Joan of Arc, London: University of Minnesota Press; Schiller, Johann Christoph Friedrich von (1801). La Pucelle d'Orléans, Traduction par: J. Peyraube, Paris: Collection Etrangere; Senzig, Roger ve Marcel Gay, L'affaire Jeanne d'Arc
(2007). Editions Florent Massot; Sackville-West, Vita (1938) Saint Joan of Arc, London: Doran Doubleday; Michelet, Jules, Joan of Arc, (1957). Michigan and Newyork: University of Michigan Press; Leon, Denis, (1923). La Vérite sur Jeanne d'Arc, Paris: Libraire Paul Leymarie; Lang, Andrew (1940). La Pucelle de France, London: Nelson Editeurs; Devries, Kelly (1999). Joan of Arc a Military Leader, Gloucestershire: Sutton Publishing; Defourneaux, Marcelin (1952) La Vie Quotidienne Au Temps de Jeanne d'Arc, Paris: Librairie Hachette; Champion, Pierre (1933). Jeanne d'Arc, Paris: Flammarion.

2 Upton Sinclair, The Jungle (1906), Frank Norris, The Pit (1903), Karl Marx, Kapital, Gustave Mayer, The History of American Fortunes (1907), Bouck White, The book of Danial Drew. A Glimpse of the Fisk-Gould-Tweed Regime from the Inside (1910), Georg Horace Lorimer, Letters from a SlefMerchand to his Son (1904).

3 'des gesicht' kelimesinin, Almanca sözlük anlamı yüzsurattır. Özdemir Nutku, adı geçen oyundaki 'Die gesichte' kelimesini 'düş' olarak yorumlamıştır (Brecht, 2000: 297). Yılmaz Onay kelimeyi sözlük anlamına sadık kalarak aktarmıştır (Kesting, 1985: 96). Bu incelemede, Özdemir Nutku'nun çevirisi dikkate alınmıştır.

\section{Kaynakça}

Bangerter, A. Lowell (1980). The Bourgeois Proletarian: A study of Anna Seghers, Bonne.

Barnes, Hazel Estella (1959). Humanistic Existentialism: The Literature of Possibility, University of Nebrasca Press.

Brecht, Bertolt (1986). Brecht On Theatre, Edited and translated by John Willet, London: Methuen. s: 10-15.

(1999). “Mezbahaların Kutsal Johanna’sı”, Bertolt Brecht Bütün Oyunları, Cilt 4, Çev: Yılmaz Onay, İstanbul: Mitos Boyut Yayınları.

(2000). "Simone Machard'ın Düşleri", Bertolt Brecht Bütün Oyunları, Cilt 8, çev: Özdemir Nutku, İstanbul: Mitos Boyut Yayınları.

Ferlier, Sami (1982). George Bernard Shaw: Bir Sanatçı-Düşünür, Ankara: Dil Tarih-Coğrafya Fakültesi Basımevi.

Kesting, Marianne (1985). Tarihte ve Çağımızda Epik Tiyatro, çev: Yılmaz Onay, Birinci basım, İstanbul: Adam Yayınları.

Leon, Denis (1923). La Vérite sur Jeanne d'Arc, Paris: Libraire Paul Leymarie.

Lukacs, György (2008). Tarihsel Roman, çev:İsmail Doğan, İstanbul: Epos Yayınları.

Meltzer, Françoise (2001). For Fear of The Fire: Joan of Arc and Limits of Subjectivity, University of Chicago Press. 
Montrose, Louis (1989). "Professing the Renaissance: The Poetics and Polistics of Culture", The New Historicism, ed. H.Aram Veeser, Newyork, London: Routledge. s: 15-36.

Michelet, Jules (1957). Joan of Arc, Michigan and Newyork:University of Michigan Press.

Nutku, Özdemir (1998). Dram Sanatı, İstanbul: Kabalcı Yayınevi.

(2007). Bertolt Brecht ve Epik Tiyatro, Birinci basım, İstanbul: Özgür Yayınları.

Nutku, Hülya (1987). Tarihsel Dram ve Cumhuriyet Dönemi Türk Tiyatrosunda Tarihsel Dram Modelleri, Ankara: Devlet Tiyatroları Yayınları, İç Eğitim Dizisi.

Oppermann, Serpil (2006). Postmodern Tarih Kuramı, Ankara: Phoenix Yayınevi.

Ortaylı, illber (1978). "Tiyatroda Tarihi Oyunlar Üzerinde Siyasal bir Analiz Denemesi”, Tiyatro Araştırmaları Dergisi, Tiyatro Eğitimi ve Ögretimi Özel Sayısı, 7: 217-232.

Seghers, Anna (1952). Jeanne d'Arc 1431 Rouen Duruşması, Çev: Aziz Çalışlar.

Senzig, Roger ve Marcel Gay (2007). L'affaire Jeanne d'Arc, Editions Florent Massot.

Schiller, Johann Christoph Friedrich von (1801) La Pucelle d'Orléans, Traduction par: J. Peyraube, Paris: Collection Etrangere.

Sullivan, Karen (1964). The Interrogation of Joan of Arc, London: University of Minnesota Press.

Sharpe, Lesley (1982). Schiller and The Historical Character, Newyork: Oxford University Press.

Shaw, Bernard; (1967). Ermiş Jeanne, Çev: Saffet Korkut, Ikinci basım, İstanbul: Milli Eğitim Basımevi.

Şener, Sevda (2008). Dünden Bugüne Tiyatro Düşüncesi, Beşinci basım, Ankara: Dost Yayınları.

Wallace, Ian (1998). German Monitor, Anna Seghers in Perspective, Amsterdam: Rodopi Editions.

White, Hayden (1973). Metahistory: The Historical Imagination in Nineteenth-CenturyEurope,Baltimore,London:TheJohnHopkins University Press. 